\title{
Limitations To Bank Negara's Ibra Guideline
}

\author{
Sherin binti Kunhibava (Corresponding author) \\ Faculty of Law, University of Malaya 50603 Kuala Lumpur \\ Tel:+603-79676567 E-mail: sherin@um.edu.my
}

\begin{abstract}
Whether a customer who defaults is entitled to ibra in Islamic financing transactions based on sale, has been the center of attention of the Islamic financial industry for a long time. Previous case-laws show that the approach of whether ibra should be granted to a defaulting customer has been inconsistent. The Shariah Advisory Council passed resolutions to address the problem but the real solution came when the Guideline on Ibra for Sale-Based Financing was issued in 2011 and last updated in 2013. The Guideline clarifies two main issues. Firstly, whether a customer who defaulted on their financing was entitled to ibra, and secondly, what the parameters for the formula for the calculation of ibra is. However, there are certain limitations to the Guideline which limit its scope of application. The focus of this research is to explain the issues that the Guideline attempted to cure and point out some limitations of the Guideline. Possible recommendations are also made to overcome the limitations.
\end{abstract}

Keywords: Ibra (rebate); Ibra Guideline; bank selling price; deferred profit; Bai-bithamin Ajil

\section{Introduction}

Ibra can be defined as 'a complete cancellation of all liabilities due upon a particular person' (ISRA 2010, p.13), it is a discharge from claims and rights, such as a creditor writing off the debts of a debtor. It is often referred to as rebate in Islamic banking and finance.

In 2011 the Central Bank of Malaysia (Bank Negara Malaysia) issued the Guideline on Ibra (Rebate) for Sale-Based Financing which was last updated in 2013. The Guideline clarifies two main issues that were plaguing the Islamic financial industry. Firstly, whether a customer who defaulted on their financing was entitled to ibra or whether it was at the discretion of the IFI to give ibra. Secondly, what the formula for the calculation of ibra is. The Islamic financial industry desperately needed the clarification because of the uncertainty of the rights of the customer vis-à-vis the bank in relation to obtaining ibra.

According to the financing agreements, a customer in an Islamic financial system has to settle the total outstanding selling price even in a sale based financing like Al Bai-bithamin Ajil (BBA), in cases of early settlement. In practise, however, Islamic financial institutions (IFIs) give ibra to its customers who make early settlement. This practice of giving ibra is important to maintain the competitiveness of Islamic banking (Mohamad \& Trakic 2013).

Although in practise IFIs give ibra to customers who settle their financing early, the situation whether ibra is granted to customers who defaulted was not clear. This is because in the past IFIs did not include a clause on ibra in the respective financing facilities documentation due to the concern that there would be uncertainty or gharar in the selling price (Dusuki, Abdul Khir, \& Muhammad, 2010; Kannaperan \& Izani, 2013).

At the same time, not including a clause stating that ibra would be granted in cases of early settlement led to many disputes as to the customer's right to ibra upon early settlement where the customer defaulted on the financing facilities. The Shariah Advisory Council (SAC) issued two resolutions, one in 2002 (SAC's $24^{\text {th }}$ meeting held on 24th April 2002) and the other in 2010 (SAC's $101^{\text {st }}$ meeting held on 20 May 2010), both attempting to address the issue of 
$i b r a$, which thereafter led to the issuance of the Guideline by BNM.

Much has been written on the issue of ibra and related case-law (e.g. Hasshan, 2013; Kabri, 2013; Mohamad \& Trakic 2013; Trakic, 2013; Chen Yeen, 2015). However little has been written on the Guideline and whether it resolves the issues on ibra in the Islamic financial industry. This research attempts to fill this gap by explaining the Guideline and whether it solves all issues in relation to ibra. The focus of this research is to explain the issues that the Guideline attempted to cure and point out some limitations of the Guideline. Possible recommendations are also made to overcome the limitations.

\section{Courts' Decision on Disputes of Customer's Right to Ibra}

As stated above, the absence of a clause on whether ibra would be granted to customers who defaulted on their financing facilities led to a number of disputes. The following section will explain the main case-law on the judges' approach in deciding the issue of whether customers were entitled to ibra. The history of case-law is discussed to understand the need for the Guideline and the issues which the Guideline was to solve.

The judges' decisions can be classified and summarized into three broad eras. The first era was the early period of Islamic banking until around 2005, during which time judges held that the right to ibra is denied to a customer that defaulted because the customer breached the financing agreements. Ibra was left at the discretion of the IFI whether to give and how much. During the second era, from after 2005 until 2010, the judges' approach was to grant ibra and in some cases to dictate the quantum, mainly on grounds of equity and justice. The third era from 2010 onwards had judges deciding in the same way as the case-law in the first era. The three eras are explained in greater detail below.

\section{First Era}

Starting with the first era, in Bank Islam Malaysia Berhad v Adnan Omar (1994) 3 CLJ 735 the Supreme Court held that the financing agreement gave the customer no right to rebate. The Supreme Court stated that rebate is practiced by the Islamic bank on a discretionary basis and the customer's failure to pay the instalments was a breach of the agreement which invoked the Islamic bank's right to terminate the facility and demand for the immediate full repayment of the facility.

This approach of the Supreme Court was followed in cases like Dato' Nik Mahmud Bin Daudv Bank Islam Malaysia Bhd (1996) 4 MLJ 295, Bank Kerjasama Rakyat Malaysia Bhd v Emcee Corporation Sdn Bhd (2003) 2 MLJ 408, and Arab Malaysian Merchant Bank Bhd v Silver Concept Sdn Bhd (2005) 5 MLJ 210.

\section{Second Era}

The second era began with the case of Affin Bank Berhad v Zulkifli Abdullah (2006) 3 MLJ 67 (hereinafter 'Affin') where the High Court under Justice Abdul Wahab Patail steered away from stare decisis and decided that an Islamic bank is not entitled to the full purchase price. The learned judge believed that if the time period for earning the profit had not passed the Islamic bank should not be entitled to the profit. The Court granted ibra and calculated the daily profit due to the Islamic bank. The case of Affin made two significant changes to precedent. Firstly, it decided that a customer defaults is entitled to ibra and secondly it fixed the selling price of the Islamic bank thus indirectly quantifying the amount of ibra due to the customer.

The decision to grant ibra to customers who defaulted was followed in cases like Malayan Banking Berhad v Marilyn Ho Siok Lin (2006) 7 MLJ 249 (hereinafter 'Marilyn'), Malayan Banking Berhad v Yakup bin Oje \& Anor (2007) 6 MLJ 398 (hereinafter 'Yakup'), Arab Malaysian Finance Bhd v Taman Ihsan Jaya Sdn 
Bhd \& Ors (Koperasi Seri Kota Bukit Cheraka Bhd, third party) (2008) 5 MLJ 631 (hereinafter 'Taman Ihsan Jaya'), and Bank Islam Malaysia Bhd v. Azhar Osman \& Other Cases (2010) 5 CLJ 54 (hereinafter 'Azhar Osman').

The main reason the cases Yakup, Marilyn (Chen Yeen, 2015), and Taman Ihsan Jaya followed Affin was to ensure equity and justice to the customer. In Azhar, Justice Rohana held that the practice of granting ibra by Islamic banks was a custom which the learned judge implied into the agreement and thus granted ibra.

As for fixing the quantum of ibra entitled to the customer, the cases Marilyn, and Taman Ihsan Jaya calculated the quantum of daily profit entitled to the Islamic bank, but the cases Yakup and Azhar Osman did not. Both these latter cases left it to the Islamic bank to calculate the ibra according to the unexpired period where profit had yet to be earned.

\section{Third Era}

The third era began with the case of Bank Islam $v$ Mohd. Azmi bin Mohd. Salleh Civil Appeal: W-02-609-2010 (hereinafter 'Mohd Azmi'). This case was actually the appeal case of Azhar. Here the Court of Appeal held that ibra is given in early settlement and not for default cases, which is at the Islamic bank's discretion, quantification is also at the Islamic bank's discretion. The Court of Appeal gave effect to the full sale price. Thus in effect following the ratio decidendi of the cases from the first era.

This decision to leave it at the IFI's decision whether to grant ibra in default cases was followed in cases like CIMB Islamic Bank Bhd v. LCL Corporation Bhd \& Anor (2011) 7 MLJ 594, Bank Kerjasama Rakyat Malaysia Bhd v. Flavour Right Sdn Bhd \& Ors [2013] 1 CLJ 810, Kuwait Finance House (Malaysia) Bhd v AC Property Development Sdn Bhd (2013) 1 LNS 1253 and Bank Pembangunan Malaysia Bhd v Mensilin Holdings Sdn Bhd \& Ors (2015) 1 LNS 442 (hereinafter 'Mensilin').
From the above summary of case-law during the three eras it can be concluded that the state of affairs of the customers' right to ibra was a rocky road. The third era seems to have settled the issue somewhat in deciding that ibra is granted only in cases of early settlement but not in default cases, where the granting of $i b r a$ and its quantification is at the bank's discretion. However, this decision to leave ibra and its quantification at the Islamic bank's discretion, did not, in my opinion, give justice to the customer. The customer then would be at the mercy of the Islamic bank as to whether ibra would be given, and if given, what the quantum would be. It is definitely necessary for Islamic banks to clarify the situation for the customer as this was recognized by the SAC in its 101st meeting held on 20 May 2010 resolution when it stated (Bank Negara Malaysia, 2010):

The SAC, in its 101st meeting dated 20 May 2010, has resolved that Bank Negara Malaysia as the authority may require Islamic financial institutions to accord Ibra to their customer who settled their debt obligation arising from the sale-based contract (such as bai bithaman ajil or murabahah) prior to the agreed settlement period. Bank Negara Malaysia may also require the terms and conditions on Ibra to be incorporated in the financing agreement to eliminate any uncertainty with respect to customer's entitlement to receive Ibra from Islamic financial institution. The Ibra formula will be determined and standardised by Bank Negara Malaysia.

Following this resolution the Guideline was passed by Bank Negara Malaysia.

\section{The Clarity Provided by the Guideline}

The Guideline which was first issued in 2011 November and later updated, provides the following significant clarification in relation to customers who defaulted on their financing agreement which are sale based:

1. IFIs are required to grant ibra to all 
customers who settle their financing before the end of the financing tenure. Settlement prior to the end of the financing tenure by the customers shall include settlement by customers in the case of default.

2. IFIs must grant ibra to (i) all existing customers who have ongoing financing contracts with the IFIs which were entered into prior to the effective date of 1 st November for IFIs and 31st January 2013 for takaful operators; and (ii) all new customers who enter into financing contracts after the effective date of 1 st November for IFIs and 31st January 2013 for takaful operators.

3. To ensure legal certainty of providing $i b r a$, IFIs are required to incorporate in their offer letter and other legal documentation related to the sale-based financing, a clause on its commitment to provide ibra. The provision on ibra must at minimum specify the following: the situation where ibra shall be granted by the IFI and the ibra formula for each situation, where relevant.

4. The parameters for the formula for $i b r a$ is:

$I b r a=$ Deferred profit - Early settlement charges And,

Settlement amount $=$ Outstanding selling price - Ibra + Late payment charges.

As can be seen from the above, the Guideline has now made it compulsory for IFIs to grant ibra even in cases of default. It is no longer the discretion of the IFI to grant ibra. The Guideline therefore does not follow the decision of the cases in the first and third era but rather followed the approach of the cases in the second era.

However the quantification of ibra as can be seen from the formula is subject to late payment charges. In cases of default the formula for the settlement amount includes not only the outstanding selling price and ibra but also late payment charges. From this we can gather two things: firstly, IFIs pleaded for the whole purchase price to be granted to them in cases of foreclosure because the ibra they would give to the customer would take into account late payment charges. Secondly, the reason why the Guideline can now require IFIs to give ibra to customers who default is because the rules on late payment charges have been clarified. It is now settled how much IFIs can charge for late payment on defaulters according to Bank Negara's Guideline on Late Payment Charges for Islamic Banking Institutions which was effective from $1^{\text {st }}$ January, 2012.

Thus the Guideline has clarified the situation for defaulters, they are entitled to ibra and there is now a formula for ibra and the settlement amount.

The next question is whether the Guideline has settled all issues on ibra.

\section{Limitations to Applicability - Not all Islamic Financing Instruments are subject to the Guideline}

One main limitation of the Guideline is that it does not apply to all Islamic financing contracts. The Guideline expressly states that it applies to sale based Islamic financing such as BBA, murabaha and bai-inah. However the Guideline expressly excludes its application on financing based on salam and istisna. The reason given in the Guideline is because the deferred delivery of the subject matter in these contracts would require a different Guideline peculiar to those contracts. What about home financing based on non sale-based contracts like Musharakah mutanaqisah or ijara? - here the answer is provided in footnote 3 of the Guideline:

IFIs are not restricted to grant rebate for financing based on other types of contracts for examples equity-based, lease-based or hybrid financing contracts, where applicable.

This means that IFIs can provide ibra for other financing transactions based on other Islamic contracts which are not BBA, murabaha or bai- 
inah. However the Guideline would seem not to apply to those transactions. If the Guideline were to apply to financing transactions other than sale based contracts of murabaha, BBA and bai-inah surely the Guideline would not have expressly stated that it applies only to those contracts. There is thus uncertainty on the application of $i b r a$ to financing transactions which are not covered by the Guideline. According to the footnote IFIs are not restricted from granting ibra in those types of contracts but at the same time it is not required for IFIs to provide ibra in cases of default.

Thus to prevent uncertainty there is an absolute necessity for either the Guideline to be extended to all Islamic financing contracts or to issue new Guideline which addresses the peculiarities of salam, istisna and other Islamic financing contracts in relation to granting ibra in cases of default.

\section{The Guideline is not being applied in the courts}

A perusal of case-law decided until the writing of this paper revealed that the Guideline has been mentioned in recent cases but not applied, for example in Malaysian Building Society Berhad v. Faza Impiana Sdn Bhd \& Ors [2012] 1 LNS 1029 Justice Mohd Zawawi stated:

[19] It is unambiguous that the right of the Plaintiff to claim the outstanding Selling Price is contractual. On that basis, the stand taken by the Defendants to question the right of the Plaintiff toward the full Selling Price when the facility was fully disbursed, for me, is not right. The issue of unaccrued profit is only material when the circumstances of the case falls under any situation enunciated in the Bank Negara Malaysia Guideline No. BNM/RH/GL 008-13 where the commitment of Ibra takes place.

From the above quotation it can be understood that the judge has taken the stand that the Islamic bank is entitled to the full selling price, and it is not correct for the customer to question this since the principle sum had been disbursed. As for ibra it would seem that the judge did not discuss it in sufficient depth but rather mentioned that it would be given if it falls within one of the situations found in the Guideline. In actual fact the Guideline very clearly states that ibra is to be granted in cases of default. Therefore the judge should have applied that in the judgement.

In the case of Kuwait Finance House (Malaysia) Berhad V. AC Property Development Sdn. Bhd. \& Ors [2013] 1 LNS 1253-

Counsel for plaintiff submitted that Bank Negara issued a Guideline that states with effect from 1st July 2012, Islamic Financial Institutions are required to incorporate in their letter of offer and legal documentations a clause on its commitment to provide Ibra. The MTQ Facility Agreement in question was executed on 18th September 2009. Counsel for defendants agreed that the provision of "ibra" was not a compulsory requirement at the time of the MTQ Facility Agreement. However, he argued as follows:

"... ibra as an accepted principle in the Religion of Islam had always been there and the SAC resolution on ibra at a later time would not render the absence of the provision on ibra in the Facility Agreement Shariah compliant.

It would seem in this case the Guideline has been mentioned but was not applied because the date of the Guideline's application was after the transaction was entered into by the parties in this case. The defense counsel then tried to argue that the absence of a clause on ibra would render the Islamic financing documentation not Shariah compliant. This the Court held was incorrect because both Bank Negara Malaysia and the IFI's Shariah supervisory board had approved the Islamic facility. The judge Ravinthran Paramaguru then went on to state:

In any event, on the facts of this case, the 1st defendant is not entitled to any rebate because 
as they did not make full settlement of the outstanding amount owing prior to the expiry of the Availability Period. For all the above reasons, I find that the absence of the provision for "ibra" in the MTQ Facility Agreement does not vitiate the agreement and absolve the defendants from liability to pay the outstanding amount.

From the above it can be seen that the judge held that in cases of default the customer is not entitled to ibra. It could be that the decision by the judge is justified as the Guideline may not have been in operation at the time of the transaction. According to the Guideline, as stated above, the Guideline is to apply to all existing customers at the time the Guideline was issued. Since the Guideline was issued in 2011 (first version) this could have been after the financing facility between the Islamic bank and customer was terminated due to default. The case was filed in 2011 and exactly when the customer defaulted was not mentioned in the case. Chances are the customer defaulted before the Guideline took effect and therefore the Guideline did not apply to the parties in this case.

In the most recent case of Mensilin (cited above), the defendants had entered into a number of istisna facilities with the IFI, these istisna facilities were later restructured to BBA and other facilities when the defendants were unable to pay on the istisna facilities. Later the defendants defaulted on the BBA facilities. The facts of the case indicate that the breach or default occurred around August 2013. This means the financing facilities were in existence when the Guideline was issued, and therefore the Guideline should have been applied in this case. However, the Guideline was neither mentioned nor applied. In the judgement Justice Mohd Asmabi stated the following at paragraph 55 of the judgement:

[55] In this case the defendants had not shown that there were early payments made to settle the amount under the Restructured Facilities
Agreements to be entitled to Ibra. ... Without any evidence having been adduced in the affidavits filed herein to show that there was early payment made it was rather mischievous for the learned Counsel to submit that the 1st defendant was entitled to a rebate and/or Ibra. This point of submission is devoid of any merit and ought to be rejected by this Court (see the case of Bank Islam Malaysia v. Mohd Azmi bin Mohd Salleh, (Rayuan Sivil No. W-02-609-2010) Unreported $C A \ldots$...

As can be seen from the quotation the learned judge followed the decision of the Court of Appeal in Mohd Azmi in deciding that where the customer defaults they are not entitled to ibra. This case is significant because it was decided after the Guideline was issued, but it did not mention nor did it apply the Guideline at all and instead followed the decision of the Court of Appeal in Mohd Azmi.

It could be that the Guideline was not brought to the attention of the judge by the counsels in the case, and therefore it was not applied. On the other hand it could be due to the non-binding effect of the Guideline on the courts. This is because while it is compulsory under statute, s.29(3) of the Islamic Financial Services Act 2013, for IFIs to comply with the standards and Guideline issued by Bank Negara, it would seem that the courts need only to comply with the resolutions of the SAC according to s. 56 of the Central Bank of Malaysia Act 2009, not the standards or Guideline issued by Bank Negara.

Section 29(3) of the Islamic Financial Services Act 2013 provides the following:

29. (3) Every institution, its director, chief executive officer, senior officer or member of a Shariah committee shall at all times comply with the standards specified by the Bank under subsections (1) and (2) which are applicable to such person.

While s.56(1) of the Central Bank of Malaysia Act 2009 provides the following:

56. (1) Where in any proceedings relating to 
Islamic financial business before any court or arbitrator any question arises concerning a Shariah matter, the court or the arbitrator, as the case may be, shall-

(a) take into consideration any published rulings of the Shariah Advisory Council,

Thus it is not compulsory for the courts to be bound by the Guideline and this is a limitation to the application of the Guideline at the courts This is so especially when there is a precedent of a higher court (Mohd Azmi) which is at cross roads with the Guideline, and the High Court is left with whether to follow precedent which is binding or the Guideline which is not binding. The choice is clear the courts will follow precedent. This is therefore a severe limitation to the application of the Guideline.

The only recommendation that can be afforded in this case, for the Guideline to be effective at the courts, is for a higher court to set the precedent by quoting and applying the Guideline in an appeal case.

\section{The Guideline does not apply completely retrospectively}

Another limitation of the Guideline is that it does not apply to all financial transactions due to the date of the cut-off period. The Guideline applies to all existing customers who have ongoing financing contracts with the IFIs which were entered into prior to the effective date of $1^{\text {st }}$ November 2011 for IFIs and $31^{\text {st }}$ January 2013 for takaful operators; and all new customers who enter into financing contracts after the effective date of 1 st November 2011 for IFIs and $31^{\text {st }}$ January 2013 for takaful operators. Which means that if the customer defaulted on the financing facilities before the 1 st of November 2011 the Guideline would not apply and ibra would be at the discretion of the IFI.

This limitation can easily be rectified if the Guideline were given absolute retrospective effect so that any customer who defaults would be entitled to ibra and the formula would be as found in the Guideline.

\section{Conclusion}

The Guideline has been issued by Bank Negara to overcome the uncertainty or ambiguous position of a customer who defaults. Case-law in the past illustrate the inconsistent approach of judges when faced with customers who defaulted. The first and third era of cases have taken the position that customers who defaulted had to pay the full purchase price and ibra is left at the discretion of the IFI. It was only in the second era that the case-law decided that ibra must be given by the IFI, except that quantification be decided either by the courts or left to the discretion of the IFI. The Guideline has in theory solved the issues of customers who defaulted by firstly requiring IFIs to grant ibra in cases of default and secondly by coming out with parameters on how to calculate ibra.

However, there are limitations on the application of the Guideline. Firstly, the Guideline does not apply to all Islamic financing transactions. Expressly the Guideline applies to sale based financing like Murabaha and $B B A$, expressly excluded are the deferred contracts of salam and istisna. As for other types of Islamic financing transactions the Guideline does not discourage the IFIs from practicing ibra. However, the Guideline does not apply to those other Islamic financing transactions. The Guideline's scope of application is thus limited.

Secondly, a perusal of recent case-law shows that the courts have so far not applied the Guideline, rather, the courts seem to follow the position that it is still at the discretion of the IFI whether to give ibra and what the quantification of ibra should be.

Thirdly, the Guideline does not apply completely retrospectively. There are cut-off periods of time and thus customers who defaulted before the cut-off period will not be entitled to rely on the Guideline. 
Recommendations to solve the limitations are simple. First, the Guideline should be extended to all Islamic financing contracts or new guidelines should be issued which address the peculiarities of salam, istisna and other Islamic financing contracts in relation to granting ibra in cases of default. Second, for the Guideline to be effective at the courts, a higher court has to set the precedent by quoting and applying the Guideline in an appeal case. Third, the Guideline should be applied retrospectively effect so that any customer who defaulted would be entitled to ibra and the formula would be as found in the Guideline.

\section{References}

Bank Negara Malaysia. (2010). Shariah Resolutions in Islamic Finance. Second Edition. Bank Negara Malaysia, Kuala Lumpur.

Chen Yeen, J. M. (2015). Al-Bai' Bithaman Ajil: The Grant of Ibra in Customer De-Fault Situations. Malayan Law Journal Articles, 5, $1-18$.

Dusuki, A.W., Abdul Khir, F., \& Muhammad, M. (2010). Implimentasi Ibra Dalam Produk Berasaskan Harga Tangguh Dalam Sistem Perbankan Islam: Analisis Dari Perspektif Operasi Perbankan Dan Maqasid Syari'ah. ISRA Research Paper, 16/2010.

Hasshan, H. (2013). Foreclosure Proceedings Involving Islamic Banking Facilities: The Current Legal and Shariah Development Within The Conventional Statutory Framework. Malayan Law Journal Articles., 2: lii-lxxviii.

ISRA. (2010). ISRA Compendium for Islamic Financial Terms. ISRA, Kuala Lumpur.

Kabri, A. S. A. (2013). Islamic Banking: Its An Evolution. Malayan Law Journal Articles, 1:1xix-1xxix.

Kannaperan, J. \& Izani, I. (2013). Guideline on Ibra for Sale Based Financing and on Late
Payment Charges. Legal Network Series Ariticles, 1, 1-14.

Mohamad, A. H. \& Trakic, A. (2013). Application and Development of Ibra in Islamic Banking in Malaysia. The Law Review, 26-51.

Trakic, A. (2013) Quantum of Claim By Islamic Banks In BBBA Contracts: Applicability of Ibra In Default Cases In Malaysia. Malayan Law Journal Articles, 4: c-lxxxiv.

\section{Cases}

Affin Bank Berhad v Zulkifli Abdullah (2006) 3 MLJ 67

Arab Malaysian Finance Bhd v Taman Ihsan Jaya Sdn Bhd \& Ors (Koperasi Seri Kota Bukit Cheraka Bhd, third party) (2008) 5 MLJ 631

Arab Malaysian Merchant Bank Bhd v Silver Concept Sdn Bhd (2005) 5 MLJ 210

Bank Islam Malaysia Berhad v Adnan Omar (1994) 3 CLJ 735

Bank Kerjasama Rakyat Malaysia Bhd v Emcee Corporation Sdn Bhd (2003) 2 MLJ 408

Bank Kerjasama Rakyat Malaysia Bhd v. Flavour Right Sdn Bhd \& Ors (2013) 1 CLJ 810

Bank Islam v Mohd. Azmi bin Mohd. Salleh Civil Appeal: W-02-609-2010

Bank Islam Malaysia Bhd v. Azhar Osman \& Other Cases (2010) 5 CLJ 54

Bank Pembangunan Malaysia Bhd v Mensilin Holdings Sdn Bhd \& Ors (2015) 1 LNS 442

CIMB Islamic Bank Bhd v. LCL Corporation Bhd \& Anor (2011) 7 MLJ 594

Dato' Nik Mahmud Bin Daud v Bank Islam Malaysia Bhd (1996) 4 MLJ 295 
Kuwait Finance House (Malaysia) Berhad V. AC Property Development Sdn Bhd \& Ors (2013) 1 LNS 1253

Malayan Banking Berhad v Marilyn Ho Siok Lin (2006) 7 MLJ 249

Malaysian Building Society Berhad v. Faza Impiana Sdn Bhd \& Ors (2012) 1 LNS 1029

Malayan Banking Berhad v Yakup bin Oje \& Anor (2007) 6 MLJ 398 